\title{
The Role of Peer- and Self-Assessment in Developing Saudi EFL Learners’ English Writing Skills
}

\author{
Manal Alshammari ${ }^{1, *}$ \\ ${ }^{1}$ School of Education, Communication and Language Sciences, Newcastle University, \\ Newcastle upon Tyne, NE1 7RU, UK \\ *Correspondence: School of Education, Communication and Language Sciences, Newcastle \\ University, Newcastle upon Tyne, NE1 7RU, UK. Tel: 44-749-040-7898. E-mail: \\ M.O.R.Alshammari1@newcastle.ac.uk
}

Received: August 6, 2016 Accepted: August 28, 2016 Published: September 22, 2016

doi:10.5296/ije.v8i3.9853ＵRL: http://dx.doi.org/10.5296/ije.v8i3.9853

\begin{abstract}
The current study focuses on the importance of integrating peer- and self-assessment in teaching English as a second/foreign language in Saudi Arabia. It pays special attention to the mechanisms by which Saudi EFL learners can improve their English writing skills if they engage in peer- and self-assessment regularly. To this end, the researcher administered a writing composition task to measure the participants' ability to express themselves in good English, focusing on the coherence, cohesion, word choice, spelling, punctuation, and layout of their essays. The researcher utilised the experimental two-groups design of a pre-test and a post-test, in order to evaluate the participants' performance prior to the application of the treatment (i.e. peer- and self-assessment) and after it. For the purpose of the study, the participants were divided into two groups: students in group A (i.e. the treatment group) engaged in peer- and self-assessment regularly throughout the term, whilst students in group B (i.e. the control group) did not. The results of group A on the pre-test and post-test were compared to those of group B to determine whether the treatment had any impact on their performance. The results reveal that group A outperformed their group B counterparts on the post-test. The statistical analysis demonstrates that the difference between the results of the two groups was statistically significant, suggesting that the treatment contributed positively to the performance of the treatment group. Finally, the study concludes with recommendations for further research.
\end{abstract}

Keywords: Education, peer-assessment, self-assessment, Saudi EFL learners, pre-test, post-test, L2 writing skills. 


\section{Introduction}

The development of effective peer- and self-assessment is demanding, since it requires considerable time and effort. However, once fully integrated into learning, peer- and self-assessment can be particularly effective in motivating students to move forward and acquire new skills (Boud, 1995; Fallows \& Chandramohan, 2001; Fredricks et al., 2004; Boud \& Falchikov, 2005; Bryant \& Carless, 2010; among others). Peer-assessment can help students understand the different types of feedback that can be provided, and how each type can enhance the ability of others to improve their work. It also helps students think about the learning objective and the criteria based on which they can provide their feedback to others. Having evaluated the work of others, students find it rather easy to assess their own work and determine how they can improve it. According to Shrauger and Osberg (1981), self-assessment may not be as good as external assessment, since people have a tendency to reflect a good image about themselves. In spite of these limitations, different types of self-assessment such as self-testing, checklists, self-reports, diaries, etc. have asserted their validity in various contexts, such as language skills, problem solving, decision-making, planning, and organising (Oscarson, 1997). In Saudi Arabia, the focus has always been on external evaluation, where the teacher marks the exams and provides feedback. Little attention is given to peer- and self-assessment, and the means by which they can enhance Saudi EFL learners' English proficiency level. Thus, this study aims to bridge this gap; specifically, it evaluates the extent to which peer- and self-assessment can improve Saudi EFL learners' English writing skills. The researcher utilised the experimental two-groups design of a pre-test and a post-test in order to assess the participants' performance prior to the application of peer- and self-assessment and after it. The next section provides an overview of peer-assessment, self-assessment and their application in Saudi Arabia.

\section{Literature Review}

\subsection{Peer-Assessment}

Essentially, peer-assessment is concerned with students' use of criteria to make judgments about the work of their peers in addition to providing comments and/or marks (Bryant \& Carless, 2010, p. 5). This type of assessment can be carried out in different ways (Fallows \& Chandramohan, 2001, p. 232). Firstly, assessment of two individuals; here, the focus is on assessing detailed and extensive pieces of work, such as essays and reports (Fallows \& Chandramohan, ibid). Secondly, assessment of all classmates or colleagues (could be either individually or in groups); this type of assessment is applied to tasks like posters and oral presentations, rather than long essays (with the exception of classes that are small in size). Indeed, oral presentations make it possible for a group of students to make judgments about the performance of the presenter. Students can learn comfortably when they compare their works to that of others; the students feel more encouraged to express their opinion, ask questions and discuss options that can enhance the presenter's performance (see Deakin-Crick et al., 2005). This environment of collaborative learning positively influences students' cognitive development and promotes enjoyment of learning (Fredricks et al., 2004). 
Additionally, in the first two types of peer-assessment mentioned above, it is expected that the assessment can contribute to students' learning via exposure to new materials written by their peers. Thus, the students are not only acquiring new skills in assessing the work of others, but they are also acquiring new knowledge through reading their peers' work. Finally, the third type of peer-assessment, according to Fallows and Chandramohan (2001, p. 232), involves group assessment, where the focus is on the performance of the group members and contributions to a group-based task.

In practice, several studies have asserted the significance of involving students in the assessment process via peer-assessment (Boud et al., 1999; Fallows \& Chandramohan, 2001; Van Zundert et al., 2010; Bryant \& Carless, 2010; among others). In a recent study, Bryant and Carless (2010) evaluated the role of peer-assessment in the development of students' learning and thinking skills. The two researchers focus on the way students and teachers perceive peer-assessment in Hong Kong primary schools. The study is based on data collected through conducting extensive interviews, together with classroom observations from a case study that lasted for two years. The results of the study show that many students view peer-assessment as a way of improving their performance. The results also demonstrate that peer-assessment establishes a sense of competition; when the students know that their peers will read and assess their work, they become motivated to work harder and produce better work every time (Bryant \& Carless, 2010). The competition also encourages students, who are academically good to work harder to keep their level and attempt to improve their performance. The next section sheds light on self-assessment and its practical manifestations.

\subsection{Self-assessment}

According to Falchikov and Boud (1989), self-assessment is concerned with the involvement of students in making judgements about their learning, in particular, about their accomplishments and the outcomes of their learning. Self-assessment is a method used in education to increase the role of students in their own learning (Boud, 1995). This type of assessment is mainly used for formative assessment purposes (i.e., assessment that provides feedback) in order to promote students' reflection on their own learning process and outcomes (Sluijsmans et al., 1998). Generally, according to Brown and Harris (2013), self-assessment can be divided into three main types: self-ratings, self-estimates of performance on formal assessments, and rubric-based assessments. Black and Harrison (2001) indicate that in self-rating, students are required to make judgments about the quality or quantity of their work by means of a rating system such as a checklist. Todd (2002) posits that the second type of self-assessment, self-estimate of performance, refers to marking one's own work by means of a marking guide that contains questions answered objectively or a model answer. Finally, Andrade and Valtcheva (2009) explain that rubric-based assessments arrange quality indicators in a cumulative manner, helping students to evaluate various aspects of their work, especially writing skills assessment.

According to Boud and Falchikov (2005), self-assessment includes two main elements. The first element is the development of knowledge as well as an appreciation of the proper criteria to take into account while making judgments about a certain work. The second element is the 
ability to judge whether the work under examination meets these criteria or not. Furthermore, self-assessment has unique characteristics, including being criterion-referenced (Andrade \& $\mathrm{Du}, 2007)$. The criteria which are used to judge the performance of students should be transparent, resulting in the students learning the necessary skills to assess their work in a way similar to that of teachers. Being criterion-referenced is highly important, since it facilitates students' goal-setting and self-reaction (Andrade \& Du, 2007). The second characteristic is concerned with facilitating students' learning through providing themselves with feedback on their own work (Horner \& Shwery, 2002). According to Schunk and Ertmer (2000), this may result in the students' reaching the highest level in strategy use and better degree of self-efficacy. The students can also achieve an understanding of the objective of self-assessment and develop critical thinking skills and empathy with teachers (Orsmond et al., 1997). In self-assessment practice, teachers share with their students their expectations for desired outcomes, usually via providing the students with a rubric. Thus, self-assessment can increase students' responsibility for their own learning and improve the relationship between students and teachers (Shepard, 2000).

Through reviewing several studies conducted on the use of self-assessment in fostering students' learning skills, the researcher found that many scholars provided positive feedback on self-assessment. With regard to second language (L2) learning, McNamara and Deane (1995) developed a number of tasks that improve self-assessment, e.g. keeping a daily language learning log, writing letters to the teacher, and preparing an English portfolio. The researchers argue that these tasks help students document their progress, determine their strengths and weaknesses in English, and acquire useful learning strategies and resources. The participants also became aware of the learning contexts which are suitable for them and learned to set objectives for future independent learning. Similarly, according to Butler and Lee (2010), self-assessment has helped students learn a second language through increasing their confidence. The two researchers indicate that in the case of Korean EFL learners, the English proficiency level of the participants, who were asked to do self-assessment regularly in their English classes throughout the term, improved remarkably in comparison to those who did not. The next section provides an overview of the application of peer- and self-assessment in Saudi Arabia

\subsection{Application of Peer- and Self-Assessment in Saudi Arabia}

It is observed that the integration of peer- and self-assessment in the curriculum in Saudi Arabia is very recent and is limited to certain fields, such as medicine. According to Cassidy (2003), learning in the Middle East, including Saudi Arabia, seems to be affected by historical and cultural norms, which are rooted in memorisation and recall of memorised information. Therefore, the general attitude towards learning is superficial and reproductive (Yusuff, 2014). Historically, the attitude towards learning resulted in inadequate skills to perform self-evaluation and monitoring, and manage learning in an effective way; it also resulted in a lack of commitment towards self-reflective practices on the long term (Allison, 2006). Additionally, Cassidy (2003) argues that this attitude towards learning may be responsible for bad study habits, self-satisfaction when one does the minimum amount of study and a lassie faire attitude towards deep learning in Saudi Arabia. 


\section{Macrothink Institute ${ }^{T M}$}

However, Yusuff (2014) proposes that this negative attitude towards learning in Saudi Arabia can be changed through following new teaching and assessment practices, which focus on deep learning and encourage the culture of self-evaluation, self-regulation and self-efficacy. The use of these new strategies may help students acquire the necessary skills to improve their performance, e.g. as clinical pharmacists in Saudi Arabia (Yusuff, 2014, p. 268). Through examining $4^{\text {th }}$ year students, studying at the College of Clinical Pharmacy in Saudi Arabia, Yusuff (2014) notes that peer- and self-assessment have changed students' attitudes towards their old ineffective study habits. These new methods of assessment help students become high-achievers and acquire the thinking skills that enable them to become more critical, rather than just memorising facts (Yusuff, 2014). When the students notice that their marks are getting higher, their self-confidence and academic experience improve remarkably.

Even though it is relatively new, on the basis of the above, it seems that the application of peer- and self-assessment in Saudi Arabia has been regarded as necessary and beneficial in medical fields. Thus, it is suggested that curriculum designers in Saudi Arabia need to start integrating peer- and self-assessment in education at various fields and levels. In this context, reference to Falchikov (2004) is in order. In her study, Falchikov (2004, p. 104) argues that setting up peer- and self-assessment requires careful preparation, monitoring and follow up procedures. Table 1 illustrates these procedures:

Table 1. Carrying out peer- and self-assessment (adapted from Falchikov, 2004, p. 104)

\begin{tabular}{|c|c|c|c|}
\hline Preparation & implementation & Follow up and evaluation & Replication \\
\hline $\begin{array}{l}\text { - Careful design of the } \\
\text { study } \\
\text { - Providing the rationale to } \\
\text { the students } \\
\text { - Giving students clear } \\
\text { instructions pertaining to } \\
\text { all stages of the process, } \\
\text { e.g. how to express } \\
\text { disagreement, the extent } \\
\text { to which grades are } \\
\text { important, etc. } \\
\text { - Identifying the criteria } \\
\text { (written by the students } \\
\text { and discussed with the } \\
\text { teacher) } \\
\text { - Preparing a checklist in } \\
\text { which the criteria are } \\
\text { listed and ranked }\end{array}$ & 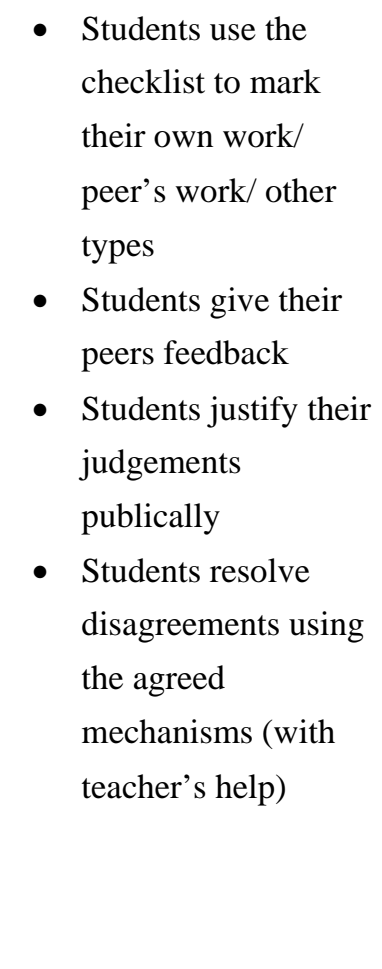 & $\begin{array}{ll}\text { - } & \text { Collecting feedback } \\
\text { (formally or } \\
\text { informally) via } \\
\text { standardised } \\
\text { instruments } \\
\text { - } & \text { Analysing feedback } \\
\text { - } & \text { Identifying problems } \\
\text { - } & \text { Making } \\
\text { modifications when } \\
\text { needed }\end{array}$ & $\begin{array}{l}\text { - Repeating the } \\
\text { exercise with the } \\
\text { same cohort }\end{array}$ \\
\hline
\end{tabular}


The preparation process requires careful explanation of the rationale of the process to the students, since it is very important for the students to understand the process fully from the beginning. Giving examples of successful application of peer- and self-assessment is very useful, because it helps students overcome their concerns about the new practice (Falchikov, 2004). The use of rating scales or checklists can be applied to both peer- and self-assessment. According to Panadero and Jonsson (2013), the use of rubrics is very helpful in self-assessment. The rubrics or checklists could be designed by potential users, including the criteria agreed on by students and teachers. Pre-existing rubrics can be also used to serve particular purposes (Falchikov, 2004). Following peer- and self-assessment, feedback is provided and judgements are justified (Falchikov, 2004). Disagreements need to be resolved on the basis of the agreed mechanisms by the students and teachers. Evaluative feedback is generated in order to develop correct practices or to conduct research. When necessary, changes should be made to rectify any problems. Finally, replication takes place to establish the new practices on the long-term (Falchikov, 2004). This is very important in the case of Saudi Arabia, since peer- and self-assessment is relatively new. Monitoring students' performance and development over time is helpful to identify any problems and overcome them in the future.

Of course, the application of a new practice may involve students' dislike of the idea behind the practice or the experience of being engaged in peer- or self-assessment. This can be due to various reasons (Falchikov, 2004). For example, students may lack confidence to assess their own work or that of others; they doubt their ability to make fair judgements. In Saudi Arabia, student may find the idea of marking others' work or their own strange, indicating that it is the job of the teacher to mark not theirs. Some students may fear that giving a low mark to a colleague may sabotage their relationship. Solutions to these problems could be: (1) discussing any problems the students encounter with the teacher; (2) asking students to justify their marks; (3) making assessment anonymous; and (4) helping students see that peer- and self-assessment is only done for formative purposes (Falchikov, 2004, p. 105).

Based on the above literature, it is suggested that if these practices are followed in Saudi Arabia, the integration of peer- and self-assessment can be applied in education at various levels. Peer- and self-assessment has been exclusively applied in the field of medicine. No study, to the best of my knowledge, has been conducted to evaluate the impact of peer- and self-assessment on the English proficiency level of Saudi EFL learners. Thus, this has provided a motivation for conducting the current study. In particular, this study aims at providing answers to the following research questions:

1) To what extent does the application of peer- and self-assessment improve Saudi EFL learners' English writing skills?

2) Are there any statistical differences between the performance of the treatment group and the control group on the pre-test and post-test? 


\section{Methodology}

\subsection{Sample}

Sixty Saudi EFL learners, students at Shihiyyah High School for Girls in Hail/Saudi Arabia, were involved in the current study. The participants' mean age was 16 years old. At the time of the study (i.e., the second term of the academic year 2014/2015), the participants were all $10^{\text {th }}$ graders, who have studied English for 6 years. For the purpose of the study, the 60 participants were equally divided into two groups: group A consisted of 30 students and group B included 30 students. The members of group A engaged in peer- and self-assessment regularly throughout the term, following Falchikov's (2004) procedure explained in Table 1. Thus, group A acted as the treatment group. In contrast, group B did not engage in peer- and self-assessment; therefore, they served as the control group. Several studies have employed this experimental method to test various aspects of performance. This method has proven its validity in testing the usefulness of a number of treatments (cf. Boruch, 2007; Cook, 2003; Zaid, 2011; among others). The participants were divided into two groups in order to determine whether the treatment (i.e., peer- and self-assessment) influenced their performance on the post-test, which evaluates their English writing skills.

\subsection{Treatment}

According to several scholars (e.g., McNamara \& Deane, 1995; Boud, 1995; Fallows \& Chandramohan, 2001; Fredricks et al., 2004; Falchikov, 2004; Butler \& Lee, 2010; Bryant \& Carless, 2010; Yusuff, 2014; among others), integrating peer- and self-assessment in the curriculum yields fruitful results, through enhancing students' thinking skills and language proficiency. In Saudi Arabia, the application of these types of assessment has been exclusive to medical fields (Yusuff, 2014). Since the application of these types of assessment has been a success so far, the current study attempts to determine the usefulness of such assessments in the context of EFL learning, especially the participants' English writing skills. Therefore, the treatment (i.e., peer- and self-assessment) was applied regularly to group A (i.e., the treatment group) for one term, while group B (i.e., the control group) did not engage in peerand self-assessment, in order to compare their results.

\subsection{Procedure and Tool}

In order to assess the participants' English writing skills, the researcher employed the same writing composition task as the pre-test and the post-test, in which the participants were asked to write a story about an interesting event that happened in their life. The pre-test was administered at the beginning of the term (i.e., the second semester of the academic year 2014/2015), whereas the post-test was carried out at the end of the term in order to make a comparison between the results of the two groups. This tool has proven its validity in testing students' productive skills, which can be utilised to learn other types of skills, such as receptive skills (Zhu, 2004). According to Dovey (2010), writing instruction can be best carried out via adopting an approach that focuses on brainstorming, collaborative learning through the presence of an audience, and multiple revisions. One may argue that assessment methods such as peer- and self-assessment meet these requirements. The researcher used the 
same task as the pre-test and the post-test in order to compare the participants' results and determine whether the treatment has enhanced their English writing skills, which include relevance of the answer, sentence structure, coherence, word choice, grammar, spelling, punctuation and style (see Zaid, 2011, \& Zhu, 2004). The marking of the essays was done based on a rubric that focused on the above mentioned skills. Regarding statistical analysis, the researcher utilised a t-test (SPSS) in order to determine whether the differences between the two groups were statistically significant. The next section provides the results and discussion.

\section{Results and Discussion}

The results of both groups on the pre-test and post-test are presented in Table 2, and the results of the t-test of the post-test are shown in Table 3.

Table 2. Percentage of the marks representing good writing skills of both groups on the pre-test and post-test

\begin{tabular}{ccc}
\hline Type of test & Group A (the treatment group) & Group B (the control group) \\
\hline Pre-test & $33 \%$ & $37 \%$ \\
Post-test & $73 \%$ & $53 \%$ \\
\hline
\end{tabular}

Table 3. Results of the t-test comparing the differences between group A and group B on the post-test

\begin{tabular}{lcccccc}
\hline Type of group & No & M & SD & t & df & Sig. \\
\hline Treatment group & 30 & 7.3 & 2.4 & 2.1 & 58 & $0.020^{*}$ \\
Control group & 30 & 5.3 & 3.8 & & & \\
\hline
\end{tabular}

$P$ value $<0.05$

An examination of Table 2 shows that the results of the treatment group and the control group on the pre-test and the post-test were different. There is a substantial difference between the results of treatment group on the pre-test (33\%) and the post-test (73\%) and the results of the control group on the pre-test (37\%) and the post-test (53\%). Specifically, the treatment group outperformed its control group counterparts on the post-test (73\%) vs. (53\%). Looking at Table 3, the differences between the results of the two groups on the post-test were statistically significant; the $P$ value is less than 0.05 . These results possibly indicate that the treatment (i.e., peer- and self-assessment), which was applied to the treatment group contributed positively to their answers on the post-test. Assessing one's work and that of the others may have helped the participants improve their writing skills in English, yielding a good result on the post-test. According to Shrauger and Osberg (1981), being an observer of one's behaviour and performance usually provides more data on the basis upon which judgments can be made. Being aware of one's strengths and weaknesses can help students focus on the areas in which they lack the necessary skills. Thus, this provides them with the 
opportunity to enhance these areas more efficiently. Through engaging in peer- and self-assessment regularly throughout the term, the participants were able to diagnose their strengths and weaknesses; they focused on the latter and attempted to improve them via practicing (cf. Andrade \& Du, 2007; Bryant \& Carless, 2010). Additionally, it has been argued that learning in a collaborative environment develop students' cognitive abilities and enhance their learning skills through being exposed to new materials written by their peers (cf. Deakin-Crick et al., 2005). Therefore, one may argue that the collaborative environment created by engaging in peer-assessment has helped the participants' improve their English writing skills.

Furthermore, according to Falchikov (2004) and Panadero and Jonsson (2013), employing rubrics is very helpful in promoting peer- and self-assessment. The rubrics or checklist is probably designed by potential users and could be agreed upon unanimously by students and teachers. Rubrics can be also used to serve particular purposes. Throughout the term, the treatment group was asked to evaluate their own essays written in English or that of their peers, using certain criteria. These criteria included: (1) whether the ideas are clear and focused in a way that consistently support the subject of the essay and the audience; this also includes the use of the words in their correct context, taking into account their appropriateness and compatibility with the target culture (see Altakhaineh \& Zibin, 2014; Altakhaineh \& Rahrouh, 2015); (2) development of ideas is logical and supported with illustrative examples and evidence; (3) the organisation of the essay is coherent and supports the essay's subject, the transition between ideas and paragraphs is easy to follow; (4) the style is confident, including varied sentence structure. Adherence to correct grammatical rules, spelling and punctuation; and (5) the format or layout is correct, satisfying the assignment instructions. It is argued that these criteria have helped the treatment group make judgments about their own work or that of their peers; thus, improving their own writing skills at the same time. Through engaging in peer- and self-assessment, members of the treatment group have become more aware of the aspects they should focus on in their writing. Hence, their performance has started to improve every time they evaluate their works or the work of their peers. Excerpts from essays written by the same students on the pre-test and the post-test are provided below:

\section{Pre-test}

Student 1: The most interesting thing that happen in my life was loosing weight. I know that this is not important to people but it was very to me. Since I was five years old, I became very fat. My freinds laugh when they see me and call me names, that make me very sad and dont talk to me. It made me eat more and more until I look like elephant... Then my parents put me in camb to loose wight. And every thing changed.

Student 2: I am writing this essay to talk about something intersting that have happned in my life and changed it. many things have happened in my life; but the most important thing that have happened was meeting my best friend salwa. i was a lone and always thinking about leaving school. But when I saw salwa that give me hope a lot. 


\section{Post-test}

Student 1: Moving to Saudi Arabia was the most importat event in my life. Before moving to Saudi Arabia, I was living in Oman. Although Oman is my country, where I have many friends and family, Saudi Arabia has became my second home.

Student 2: Writing a story about something interesting that has changed my life may be difficult to write at the begining, but when I thought about it carefuly, I realised that it is easy to write. When my little sister Layla came to this life, I felt I am in heaven. I have brothers but they don't spend time with me becuase I am girl.

Examining the excerpts, it seems that the writing skills of the two students have indeed improved. They have started paying attention to the flow of ideas, sentence structure, the coherence of the text, their word choice (using words in their right context and paying attention to the appropriateness of the words in English), their grammar, punctuation, spelling, etc. For instance, it is clear that the students have become aware of important aspects of English writing, such as capitalising proper nouns (compare salwa vs. Layla,), abbreviations (compare dont vs don't), etc. Even though, the participants still produce some errors related to grammar, spelling and punctuation, their improvement is indisputable. Therefore, the integration of peer- and self-assessment in English teaching curriculum in Saudi Arabia could be very beneficial to both students and teachers.

\section{Conclusion and Recommendations}

Since the use of peer- and self-assessment is relatively new in Saudi Arabia, in this study, the researcher has discussed how these types of assessment can be applied successfully to teaching English as a second/foreign language in Saudi Arabia, especially in relation to English writing skills. The researcher employed the experimental two-groups design of a pre-test and a post-test, in order to evaluate the participants' performance prior to the application of the treatment and after it. In particular, the researcher administered a writing composition task to assess the participants' ability to express themselves in good English. The sample of the study was divided into two groups: group A (i.e., the treatment group), whose members engaged in peer- and self-assessment regularly throughout the term and group B (i.e., the control group), whose members did not. This division was done in order to determine whether the treatment influenced the treatment group's English writing skills. The results show that group A outperformed their group B counterparts on the post-test. The statistical analysis shows that the differences between the results of the two groups were statistically significant. This suggests that the treatment has helped the participants improve their English writing skills. Therefore, it is proposed that curriculum designers in Saudi Arabia need to start integrating peer- and self-assessment in education at various fields and levels. Finally, it is recommended that studies that focus on the influence of peer- and self-assessment on students' performance in various fields in Saudi Arabia are required, since they can shed light on whether these types of assessment enhance students' learning skills. 


\section{Acknowledgements}

I am grateful to all participants who took part in this study. Additionally, I would like to thank Mrs Azizah Obaid Alshammari, who collected the data.

\section{References}

Allison, A. (2006). Preparing our graduates for a lifetime of learning. American Journal of Pharmaceutical Education, 70(1), 15.

Altakhaineh, A., \& Rahrouh, H. (2015). The use of euphemistic expressions by Arab EFL learners: Evidence from Al-Ain University of science and technology. International Journal of English Linguistics, 5(1), 14-21. http://dx.doi.org/10.5539/ijel.v5n1p14

Altakhaineh, A., \& Zibin, A. (2014). Perception of culturally loaded words by Arab EFL learners. International Journal of Linguistics, 6(3), 1-22. http://dx.doi.org/10.5296/ijl.v6i3.4922

Andrade, H., \& Du, Y. (2007). Student responses to criteria - referenced self - assessment. Assessment \& Evaluation in Higher Education, 32(2), 159-181. http://dx.doi.org/10.1080/02602930600801928

Andrade, H., \& Valtcheva, A. (2009). Promoting learning and achievement through $\begin{array}{llll}\text { self-assessment. Theory into } \quad \text { Practice, } & \text { 48(1), } 19 .\end{array}$ http://dx.doi.org/10.1080/00405840802577544

Black, P., \& Harrison, C. (2001). Self-and peer-assessment and taking responsibility: The science student's role in formative assessment. School Science Review, 82, 43-50.

Boruch, R. (2007). Encouraging the Flight of Error: Ethical Standards, Evidence Standards, and Randomized Trials. In G. Julnes \& D. J. Rog (eds.), informing federal policies on evaluation methodology: Building the evidence base for method choice in government sponsored evaluation. New Directions for Evaluation, 113, 55-73. http://dx.doi.org/10.1002/ev.215

Boud, D. (1995). Assessment and learning: Contradictory or complementary. Assessment for Learning in Higher Education, 35-48.

Boud, D., \& Falchikov, N. (2005). Redesigning assessment for learning beyond higher education. Research and Development in Higher Education, 28, 34-41.

Boud, D., Cohen, R., \& Sampson, J. (1999). Peer learning and assessment. Assessment \& Evaluation in Higher Education, 24(4), 413-426. http://dx.doi.org/10.1080/0260293990240405

Brown, G. T., \& Harris, L.R. (2013). Student self-assessment. In J. H. McMillan (ed.) the SAGE handbook of research on classroom assessment (pp. 367-393). London: Sage.

Bryant, D. A., \& Carless, D. R. (2010). Peer assessment in a test-dominated setting: 
Empowering, boring or facilitating examination preparation?. Educational Research for Policy and Practice, 9(1), 3-15. http://dx.doi.org/10.1007/s10671-009-9077-2

Butler, Y. G., \& Lee, J. (2010). The effects of self-assessment among young learners of English. Language Testing, 27(1), 5-31. http://dx.doi.org/10.1177/0265532209346370

Cassidy, T. J. (2003). Education in the Arab states: Preparing to compete in the global economy. The Arab World Competitiveness Report, World Economic Forum, 218-234.

Cook, T. D. (2003). Why have educational evaluators chosen not to do randomized experiments? The ANNALS of the American Academy of Political and Social Science, 589(1), 114-149. http://dx.doi.org/10.1177/0002716203254764

Deakin-Crick, R., Sebba, J., Harlen, W., Yu, G., \& Lawson, H. (2005). Systematic review of research evidence of the impact on students of self- and peer assessment. London: EPPI Centre Social Science Research Unit Institute of Education University of London.

Dovey, T. (2010). Facilitating writing from sources: A focus on both process and product Journal of English for Academic Purposes, 9(1), 45-60. http://dx.doi.org/10.1016/j.jeap.2009.11.005

Falchikov, N. (2004). Involving students in assessment. Psychology Learning and Teaching, 3(2), 102-108. http://dx.doi.org/10.2304/plat.2003.3.2.102

Falchikov, N., \& Boud, D. (1989). Student self-assessment in higher education: A meta-analysis. Review of Educational Research, 59(4), 395-430. http://dx.doi.org/10.3102/00346543059004395

Fallows, S., \& Chandramohan, B. (2001). Multiple approaches to assessment: Reflections on use of tutor, peer and self-assessment. Teaching in Higher Education, 6(2), 229-246. http://dx.doi.org/10.1080/13562510120045212

Fredricks, J. A., Blumenfeld, P. C., \& Paris, A. H. (2004). School engagement: Potential of the concept, state of the evidence. Review of Educational Research, 74(1), 59-109. http://dx.doi.org/10.3102/00346543074001059

Horner, S. L., \& Shwery, C. S. (2002). Becoming an engaged, self-regulated reader. Theory into Practice, 41(2), 102-109. http://dx.doi.org/10.1207/s15430421tip4102_6

McNamara, M. J., \& Deane, D. (1995). Self-assessment activities: Toward language autonomy in language learning. TESOL Journal, 5(1), 17-21.

Orsmond, P., Merry, S., \& Reiling, K. (1997). A study in self - assessment: Tutor and students' perceptions of performance criteria. Assessment \& Evaluation in Higher Education, 22(4), 357-368. http://dx.doi.org/10.1080/0260293970220401.

Oscarson, M. (1997). Self-assessment of foreign and second language proficiency. Encyclopedia of Language and Education, 7, 175-187.

Panadero, E., \& Jonsson, A. (2013). The use of scoring rubrics for formative assessment 
purposes revisited: A review. Educational Research Review, 9, 129-144. http://dx.doi.org/10.1016/j.edurev.2013.01.002.

Schunk, D. H., \& Ertmer, P. A. (2000). Self-regulation and academic learning: Self-efficacy Enhancing interventions. In M. Boekaerts, P. R. Pintrich \& M. Zeidner (eds.), handbook of self-regulation (pp. 631-649). San Diego: Academic Press.

Shepard, L. A. (2000). The role of assessment in a learning culture. Educational Researcher, 29(7), 4-14. http://www.jstor.org/stable/1176145.

Shrauger, J. S., \& Osberg, T. M. (1981). The relative accuracy of self-predictions and judgments by others in psychological assessment. Psychological Bulletin, 90(2), 322-351. http://dx.doi.org/10.1037/0033-2909.90.2.322.

Sluijsmans, D., Dochy, F., \& Moerkerke, G. (1998). The use of self-, peer-and co-assessment in higher education. Heerlen: Open University of the Netherlands.

Todd, R. W. (2002). Using self-assessment for evaluation. Forum, 40(1), 16-19.

Van Zundert, M., Sluijsmans, D., \& Van Merriënboer, J. (2010). Effective peer assessment processes: Research findings and future directions. Learning and Instruction, 20(4), 270-279. http://dx.doi.org/10.1016/j.learninstruc.2009.08.004

Yusuff, K. B. (2014). Does self-reflection and peer-assessment improve Saudi pharmacy students' academic performance and metacognitive skills?. Saudi Pharmaceutical Journal, 23, 266-275. http://dx.doi.org/10.1016/j.jsps.2014.11.018

Zaid, M. A. (2011). Effects of web-based pre-writing activities on college EFL students' writing performance and their writing apprehension. Journal of King Saud $\begin{array}{llll}\text { University-Languages } \quad \text { and } \quad \text { Translation, } & \text { 23(2), }\end{array}$ http://dx.doi.org/10.1016/j.jksult.2011.04.003

Zhu, W. (2004). Faculty views on the importance of writing, the nature of academic writing, and teaching and responding to writing in the disciplines. Journal of Second Language Writing, 13(1), 29-48. http://dx.doi.org/10.1016/j.jslw.2004.04.004

\section{Copyright Disclaimer}

Copyright for this article is retained by the author(s), with first publication rights granted to the journal.

This is an open-access article distributed under the terms and conditions of the Creative Commons Attribution license (http://creativecommons.org/licenses/by/3.0/). 